\title{
A Knowledge Oriented Approach to the Investigation of Italian Banks Performances
}

\author{
Gimede Gigante, $\mathrm{PhD}$ (Corresponding author) \\ Research Fellow at University of Rome III \\ Visiting Researcher of Banking \& Finance at Columbia Business School \\ Via Silvio D'Amico, 77, Roma 00145 \\ Tel: 39-392-988-4450 E-mail:gg2410@columbia.edu \\ http://www.columbia.edu/ gg2410/ \\ Daniele Previati \\ Full Professor of Financial Institutions Management at University of Rome 3 \\ SDA Bocconi Professor of Banking and Insurance. \\ Via Silvio D'Amico, 77, Roma 00145 \\ Tel: 39-065-733-5671 E-mail: daniele.previati@sdabocconi.it
}

Received: February 21, 2011

Accepted: March 14, 2011

doi:10.5539/ijef.v3n6p12

\begin{abstract}
The purpose of this paper is to provide a description of the present role of intellectual capital (IC) in the Italian Banking Sector, giving as output a ranking representation of the banks involved in the analysis in terms of their efficient use of tangible and intangible assets in the creation of corporate value. The paper will investigate the components of IC and the impact that these components had on performance during the period 2003-2007. A multiple regression analysis is used to test the relationship between IC performance and certain independent variables. A model of analysis will be adopted from the literature in order to approximate the efficiency of banks in their use of intangible assets for the creation of value (VAIC Analysis). The results show that investors may place different values on each of the three components of value creation efficiency (physical capital, human capital, and structural capital).
\end{abstract}

Keywords: Intellectual Capital, Value Added Intellectual Capital Coefficient, Bank Perfomances

\section{Introduction}

Words like "New Economy", "Knowledge Management", and "Intangible Assets" have become part of the common vocabulary used at academic but also at operative levels in order to approximate the peculiarities of firms in this millennium. In the last few decades many studies have been conducted in order to better understand the process of dematerialization that has occurred in what is identified as the "new economy period". In consequence, value creation models, both for products and services, are becoming increasingly correlated with immaterial resources contained within them. Even considering the above-mentioned efforts, intangible resources are not a completely new phenomenon. At the beginning of the nineteenth century, due to techniques of production based on Taylor's approach (a decomposition of the product into standardized components, and the fragmentation of job activities), there has been a reduction of the content of material factors related to production, which has in turn been balanced by an increasing flow of information requested for the regulation of the production process itself. It was also during this period that companies began their transformation towards a complex system of resources, and the cognitive patrimony began to shift from production assets to an organization in its totality. There has always been immaterial content in the capitalist sphere for this reason, but only in the past few decades have intangible resources become the principle element used by firms to obtain local and global market competitiveness. Immaterial components have gained a prominent role in the modern business picture, but IC has yet to be systematically valuated. Investors ignore the profits generated through intangible capital, primarily because its role is difficult to isolate, and there are few generally accepted and standardized survey models available to provide an understanding of how this element might be developed. The following points highlight the nature of IC research conducted to date:

1. Academic efforts approximated by the presence in the literature of a consistent number of monetary models have been uitlized. Unfortunately, these efforts cannot be considered indicative of good results if we consider that no one 
model of reporting can be considered totally shared, in terms of standardization and diffusion, with the system of competition within a company in its entirity.

2. Operative efforts of those companies that, even if only in a manner of voluntary communication made at a corporate level, have tried to describe their own intangible patrimony.

There is a need to develop new means of increasing firm competitiveness, and the role of traditional accounting and measurement systems to evaluate performance appears insufficient. It is important to start this analysis with a sector for which IC is clearly recognized as an intrinsic part of growth. If production activities require both physical and IC and if within the agricultural and industrial sectors (concerned with the traditional inputs of land and labor) physical, rather than Intellectual, capital is most important in the process of wealth creation, for sure the financial sector, and in particular the banking system, is the ideal field in which to concentrate our efforts starting from the conviction that the business itself in the Banking Sector is based on high levels of intellectual knowledge (Mavridis, 2004).

This empirical study applies a relatively new financial tool, the Value Added Intellectual Coefficient (VAIC), developed by Ante Pulic (1998), which has been designed to help firms leverage their hidden potential. The key contribution of VAIC is its means of providing a standardized and consistent measure for conducting a comparative analysis across various sectors. To investigate measures of corporate performance, this study focuses on the Italian Banking System (a panel of 22 Banks specialised in four different sectors: commercial, cooperative, popular and mid term credit institutions). Using the index of VAIC, it aims to examine its association with the measure of shareholder value. The latter will be investigated in this paper and the first two in two additional papers. Before employing a multiple regression analysis, and to increase the accuracy of the results, the research analyzes the collinearity among variables. In this direction the findings will help the banks to benchmark themselves based on the levels of their efficiency rankings, suggesting priorities in their strategic plans. Moreover, this analysis will help stakeholders and investors assess the value creating potential of banks, and it will help policy makers to formulate and implement policies for the establishment of a resilient banking sector. Of course the model chosen for this paper open the door for questions regarding its own validity. This is mostly due to the fact that it unilizes information provided on financial statements and the balance sheet captures only a small portion of IC, starting from the profit of a company, which is in itself derived from all its existing resources - including IC. Thus, financial statement information in fact includes within it the effects of IC. More evidence is needed as to what factors determine IC performance before any generalization of the results can be made. In addition, the empirical tests were conducted only on a limited number of banks over the period 2003-2007 and, as such, the results of the study cannot be assumed to extend beyond this group of banks or to different study periods. The primary practical implication is that the study might help listed banks address those factors affecting their IC performance and, in turn, maximize their value creation. The originality of the paper stems from the large number of variables utilized and interpreted through empirical regressions, and the descriptive statistics that provide a thorough description of the Italian banking system through the lens of an IC perspective. The results expand upon the understanding of the role of IC in creating corporate value and building sustainable advantages for companies. This paper also tries to describe and approximate the competitive banking system in Italy from a new prospective.

\section{Literature Review}

Previous work on IC may be considered biased in one direction or another, depending on whether authors view IC as an input into the value creation process, as a value creation process in itself, or as tangible output from the firm's value creation processes. Alternative approaches that integrate various levels of analysis also view IC as a process function within and across organizations. Here, the particular organizational routines and organizational culture, which creates value, is seen as a form of capital in itself. It is important to note that the view of potential value still dominates these approaches. A final set of approaches regards IC as an output, a tangible product, or services, within which knowledge, skills, and processes in a given organization are embedded. There are numerous definitions of IC. Entrepreneurs, in particular, find that performance of IC significantly affects their firms' bottom lines. Growth of a firm's IC has been interpreted as an early indicator of subsequent performance (Ross and Ross, 1997). Corporate performance refers to the overall well-being of firms, which is measured through sales, assets, profit, book values, and market values. There has been much debate about book and market values of a firm. Traditional accounting measures book values from the balance sheet. Book value is the difference between a firm's total assets and its liabilities. In other words, if a firm sells off its entire assets and pays for all its liabilities, the remaining amount is the book value. According to traditional accounting measures, an asset refers to physical and financial capital, and IC, with the exception of goodwill, is not regarded as asset, the reason for this is that an asset, as defined by the International Accounting Standard Committee, is a resource controlled by a firm due to past actions and from which future benefits are expected. Examples of an asset are land, buildings, and machinery. Due to the intangibility of IC, it cannot be owned and controlled by a firm. For this reason, IC is not considered an asset. In fact, the finances 
needed to acquire IC are viewed solely as an expense. By excluding IC, traditional accounting therefore underestimates the true value of firms. Market values are values of firms as evaluated by the market. They are the overall values of stocks owned by a firm. In other words, they are the amount one must pay to buy the entire firm at a specific time. The rise and fall of market value depends on numerous factors, such as the firm's book value, profit level, economic outlook, and speculation regarding a firm's ability to create value. Interestingly, though not unexpected, the gap between the book and market values has been widening over time. This means the market values were bigger than the book values of the firms analyzed for this paper. Such a difference may be explained by IC. As a result, users of annual reports listed the issue of IC as one of their their top ten informational needs. Increasing attention as to the role played by IC in the value creation process has resulted in more than 20 methods of measuring IC (see www.sveiby.com). Among them are the Balanced Scorecard, developed by Kaplan and Norton in 1992, the Skandia Navigator, developed by Edivisson in 1997, the IC Index, developed by Roos in 1997, the Intangible Asset Monitor, developed by Sveiby (1997), the Economic Value Added (EVAe), by Stewart in 1997, and the VAIC, developed by Pulic in 1997. Contributions have also been made by Previati and Vezzani (2010), and by Gigante and Previati (2010). Both of these contributions center on the study of the Italian banking industry and demonstrate how intrinsic IC is to the measure of bank performance. Table 1 conveys a sense of the number of definitions of IC that exist in the literature.

\section{Methodology}

Adam Smith presented a theoretical perspective of the various business disciplines, describing and addressing the firm as an organization that obtains its resources from its investors, employees, and suppliers, in order to produce goods and services. This traditional view defines corporate performance as the financial returns to a firm's owner from the utilization of tangible resources. More recent theoretical views suggest investors, employees, suppliers, customers, and other relevant stakeholders (such as unions, government) all contribute to and receive benefits from a firm. These resource-based theories interpret firms as collections of physical and intangible assets, and of capabilitiesm, which suggests that corporate performance is a function of the effective and efficient use of the respective tangible and intangible assets within the firm. Furthermore, value added (also called wealth creation) is considered the appropriate means of conceptualizing corporate performance rather than the mere financial returns to a firm's owner. In the opinion of Firer and Williams (2003) traditional measures of corporate performance, based on conventional accounting principles of determining income, may prove unsuitable in the new economic world, where competitive advantage is driven by IC. Use of traditional measures may lead investors and other relevant stakeholders to make inappropriate decisions when allocating scarce resources. Ante Pulic (2000a, 2000b) proposed a measure of the efficiency of value added by corporate intellectual ability [Value Added Intellectual Coefficient (VAIC)] that supercedes the problems associated with directly measuring firms' IC. The components of VAIC can be divided from a firm's resource base in physical capital, human capital, and structural capital. Many advantages are associated with this interpretation (Firer and Williams 2003). Primarily, VAIC provides a standardized and consistent basis of measure, thereby enabling the effective conduct of an international comparative analysis using a large sample size within and across various industrial sectors. Alternative IC measures are limited in that they: (a) utilize information associated with a select group of firms (for example stock data); (b) involve unique financial and non-financial indicators that can be readily combined into a single comprehensive measure; and/or (c) are customized to fit the profile of an individual firm (Roos, Roos, Dragonetti \& Edvinsson, 1997; Sullivan, 2000). In addition, all data collected for the VAIC calculation is based on audited information and, therefore, VAIC calculations are objective and verifiable (Pulic, 1998; Pulic, 2000a), whereas other IC measures have been criticized due to the subjectivity associated with their underlying indicators (Williams, 2001). Concerns have also been raised about difficulties in verifying information used in calculating the indicators of other IC measures. VAIC also enhances cognitive understanding, and it enables ease of calculation by various internal and external stakeholders.

\subsection{Independent variables:}

Independent variables of the model are VAIC and its components Capital Employed Efficiency (CEE), Human Capital Efficiency (HCE) and Structural Capital Efficiency (SCE) determined from data recovered from Bankscope/Amadeus and OSIRIS (source balance sheet). It is necessary starting with the determination of the value added. Value Added (VA) is calculated as the difference between output and input. The basic definition is as follows:

$$
\text { (1) } V A=O U T-I N
$$

Where:

$\mathrm{VA}=$ value added for the company; OUT = total sales; $\mathrm{IN}=$ cost of bought - in materials, components, and services Value added can be calculated from the bank accounts also as follows: 
(2) $V A=T O I-T O E+P E$

Where:

$\mathrm{VA}=$ Total Operating Income (TOI) - Total Operating Expense (TOE) + Personnel Expenses (PE), where:

TOI $=$ Interest Income - Interest Expense $=$ Net Interest Revenue + Net Commission Revenue + Net Trading Revenue + Other Operating Income $=$ TOI

$\mathrm{TOE}=$ Personnel Expenses + Other Administrative Expenses + Other Operating Expenses + Loan Loss Provisions $=$ TOE

Value added is a totally objective indicator of business success and shows the ability of a company to create value. After VA has been calculated, the computation of the efficiency of resources - IC and financial capital - is a matter of simple mathematics. IC has two components, human and structural capital. All the expenditures for employees are embraced in human capital. What is new about this concept is that salaries and wages are no longer part of INPUT. This meets the demand for giving employees the status of key resource by treating them as investment and not any longer as cost. They invest their knowledge and skills, which is valued by the market through the company's activities and reflected in the created value added. Efficiency of human capital (HCE) is calculated as follows:

(3) $H C E=V A / H C$

Where:

$\mathrm{HCE}=$ human capital efficiency coefficient for the company;

$\mathrm{VA}=$ value added;

$\mathrm{HC}=$ total salaries and wages for company

Structural capital (SC), as the second component of IC, is calculated as follows:

$$
\text { (4) } S C=V A-H C
$$

Where:

$\mathrm{SC}=$ structural capital for the company;

$\mathrm{VA}=$ value added;

$\mathrm{HC}=$ total salary and wage.

As the equation already indicates, this form of capital is not an independent size, as is human capital. It is dependent on the created value added and in reverse proportion to HC. This means that the bigger the share of human capital (HC) in the created value added (VA) the smaller the share of structural capital (SC). In some cases SC does not even has to occur - e.g. if VA is less than the investments in HC. Because they have to be brought in the same position towards VA, the efficiency of $\mathrm{HC}$ and $\mathrm{SC}$ is calculated in a different manner. If SC were calculated in the same manner as $\mathrm{HC}(\mathrm{VA} / \mathrm{SC})$, an illogical result would be obtained, meaning that the efficiency of SC would rise with the fall of efficiency of $\mathrm{HC}$, which is impossible. Contrary to that it is logical that the efficiency of both, HC and SC, rises as the total efficiency of IC increases.

Structural capital efficiency (SCE) is therefore calculated in the following manner:

$$
\text { (5) } S C E=S C / V A
$$

Where:

$\mathrm{SCE}=$ structural capital efficiency for company;

$\mathrm{SC}=$ structural capital;

$\mathrm{VA}=$ value added

Intellectual Capital Efficiency (ICE) is obtained by adding up the partial efficiencies of human and structural capital.

(6) $I C E=H C E+S C E$

Where:

ICE $=$ intellectual capital efficiency coefficient;

$\mathrm{HCE}=$ human capital efficiency coefficient;

$\mathrm{SCE}=$ structural capital efficiency coefficient. 
IC cannot create value on its own. Therefore, we need information about capital employed efficiency, which can be calculated in the following manner:

$$
\text { (7) } C E E=V A / C E
$$

Where:

$\mathrm{CEE}=$ capital employed efficiency coefficient;

$\mathrm{VA}=$ value added

$\mathrm{CE}=$ book value of the net asset for a company.

In order to enable comparison of overall value creation efficiency, all three indicators need to be added up.

$$
\text { (8) } V A I C=H C E+C E E+S C E
$$

This aggregated indicator allows us to understand the overall efficiency of a company and indicates its intellectual ability. In simple words, VAIC ${ }^{\text {TM }}$ measures how much new value has been created per invested monetary unit in resources. A high coefficient indicates a higher value creation using the company's resources, including IC. We therefore have a new way to understand organizational efficiency.

\subsection{Dependent Variables}

MR it = Investors' capital gain on shares of firm ' $\mathrm{i}$ ' during the ' $\mathrm{t}$ ' period. Capital gain on shares is only dependent variable in the equation. Capital gain on shares can be calculated using the following equation:

(9) $M R$ it $=($ Pt1-Pt0/Pt0 $) * 100$

Where:

Pt $1=$ Market Price per share of firm $i$ at the end of the period $t$

$\mathrm{Pt} 0=$ Market Price per share of firm $\mathrm{i}$ at the beginning of period $\mathrm{t}$

\subsection{Regression Model}

$$
\text { (10) MR it }=\alpha_{0}+\alpha_{1} \text { VAIC it }+\alpha_{2} \text { HCE it }+\alpha_{3} \text { CEE it }+\alpha_{4} \text { SCE it }+\varepsilon \text { it }
$$

Market valuation or firm value is central to the calculation of capital gain. Thus, research hypotheses can be developed as follows:

H1. Firms with higher intellectual capital efficiency (VAIC) in the period generate a higher rate of capital gain.

H2a. Firms with higher human capital efficiency generate a higher rate of capital gain.

$\mathrm{H} 2 \mathrm{~b}$. Firms with higher capital employed efficiency generate a higher rate of capital gain.

$\mathrm{H} 2 \mathrm{c}$. Firms with higher structural capital efficiency generate a higher of capital gain.

\section{Results and conclusions}

This paper has analyzed the aggregate VAIC values for the Italian banks, addressing synthetic value for:

A) Saving Banks (VAIC mean equal to 2.41)

B) Commercial Banks (VAIC mean equal to 2.39)

C) Cooperative Banks (VAIC mean equal to 2.14)

D) Mid and Long Term Credit institutions (VAIC mean equal to 4.33)

E) Investment Banks (VAIC mean equal to 3.16)

Glancing at the results for each sector (Figure 1), we do not find many surprises. The high values are found in those sectors for which intellectual contribution is key to business success (Medium Long Term Credit Institutions and Investment Banks). The synthetic value added intellectual coefficient has also been calculated for each bank in a sample of 22 Italian banks (Figures 2 and 3). The analysis was conducted over a period of four years (between 2003 and 2007). Since mergers and acquisitions occurred during this period, consolidated data has been used for those banks involved in these processes. The first output is a new ranking for the Italian banks, starting with an interpretation of their efficient use of intellectual resources when creating added value. What makes this analysis innovative is the entirely new insight it provides into the quality of business performance. Those banks that had demonstrated the most financial success using traditional methods of analysis, had actually been performing poorly according to our VAIC analysis (i.e. Unicredit, with a VAIC mean of only 2.97 and Intesa Sanpaolo, with a mean of 2.67). The accuracy of the VAIC predictions was confirmed two years later, when the poor performance of these banks (possibly resulting from their poorly executed expansions between 2003 and 2007) became grossly apparent. 
Examining Figures 4 and 6, which reproduce the performance of Bank Intra, we can appreciate the explanatory meaning of the intellectual coefficient and its variables in respect to other financial performance indicators. The intellectual coefficient explains in a very intuitive manner, and in advance of more traditional measures of performance (Figure 5), how the creation of value in the years 2004 and 2005 suffers from an inefficient use of key bank resources. This is actually a very common scenario for many companies: Traditional indicators often create an illusion of success while value is actually being diminished. Management must monitor the value added (VA) produced in its organization, all the while understanding the broader picture when trying to predict the relationship between results and invested resources. The analysis presented in this paper depicts which resources (tangibles and intangibles) are creating value and which are not. (Note 1)

An additional component of this paper is the determination of capital gain value on shares for the 22 banks of the sample (source DataStream) using the multiple linear regression model to identify the relationship between investors' capital gain on shares and VAIC value. Other independent variables have not been added to the equation in order to investigate the full explanatory power of VAIC and its components (such as HCE, CEE, SCE). Output of the regression analysis is summarized in Tables 3 and 4, where the results of the descriptive statistic investigations (output of Minitab Software) are also shown. The VAIC mean for the Italian banking system overall, across the four years of investigation, is 2.4. Italian banks have a high HCE value (with a mean of 1.77) and lower values for CEE and SCE (respectively 0.27 and 0.50). In accordance with the literature (Bharathi, 2010), the results of this part of the study indicate that a major contribution to the VAIC ranking invariably comes from Human Capital efficiency. The main reason for this is that banks rely extensively on technology, which reduces their expenditure on human assets and which increases their returns for each euro invested.

In contrast to a previous analysis (Gigante, Previati 2010), in which the regression test was conducted using only the means from values across a four years span, this study engages the test on every value of the VAIC and its component calculated on every bank in the sample for each year of investigation. The total variation in capital gain on shares is shown to be $31.8 \%$ (explanatory power), resulting from a variation of the VAIC coefficient and of its components (SCE, CEE, HCE). At least one independent variable, such as human capital, structural capital, or physical capital, has a positive correlation with capital gain on shares (MRi), confirming the assumptions $\mathrm{H} 1$ and $\mathrm{H} 2$ of our analysis. This result indicates, in sum, that IC is a major corporate asset, capable of generating sustainable competitive advantages and superior financial performance for shareholders (Barney, 1991). The explanatory power of the model conveys a sense of the potency of corporate IC when generating capital gain on shares, and, as a result, a sense of the ability of IC to attract investors in the market. In accordance with that part of the literature which has measured company performance in terms of capital gain on shares (Ranjith, 2007), it is herein confirmed that IC has a positive impact on capital gain shares.

The study provides a means by which firms can formulate their business strategies so as to increase the efficiency of their resources and achieve competitive advantages over rivals. The VAIC model is an especially useful tool when analyzing service companies, such as those in the banking, finance, and insurance sectors. Given the role service companies play in developing economies, the uncharted potential of the VAIC approach in this direction should also be considered.

\section{References}

Barney, J.B. (1991). Firm Resources and Sustainable Competitive Advantage. Journal of Management, Vol. 17 No. 1, pp.99-120. doi:10.1177\%2F014920639101700108, http://dx.doi.org/10.1177\%2F014920639101700108

Bharathi, K.G. (2010). The Intellectual Capital Performance of Banking Sector in Pakistan. Pakistan Journal of Commerce and Social Sciences, 4(1), 84-99.

Bontis, N. (2003). Intellectual Capital disclosure in Canadian corporations. Journal of Human Resource Costing \& Accounting, Vol. 7 No.1/2, pp.9-20. doi:10.1108/eb029076, http://dx.doi.org/10.1108/eb029076

Bornemann, M. (1999). Potential of Value Systems According to the VAICTM Method. International Journal Technology Management, 18, 5, 463-475. doi:10.1504/IJTM.1999.002781, http://dx.doi.org/10.1504/IJTM.1999.002781

Bouty, I. (2000). Interpersonal and interaction influences on informal resource exchanges between R\&D researchers across organisational boundaries. Academy of Management Journal, Vol. 43 No. 1, pp. 50-65. doi:10.2307\%2F1556385, http://dx.doi.org/10.2307\%2F1556385

Bradley, K. (1997). Intellectual Capital and The New Wealth of Nations. Business Strategy Review, 8, pp. 53-62. doi:10.1111\%2F1467-8616.00007, http://dx.doi.org/10.1111\%2F1467-8616.00007

Brennan, N. (2001). Reporting Intellectual Capital in Annual Reports: Evidence from Ireland. Accounting, Auditing \& Accountability Journal, Vol. 14 No.4, pp.423. doi:10.1108/09513570110403443, 
http://dx.doi.org/10.1108/09513570110403443

Chen, I., Zhu, Z., Xie, H. (2004). Measuring Intellectual Capital: a New Model and Empirical Study. Journal of Intellectual Capital, Vol. 5, No. 1, pp. 195-212. doi:10.1108/14691930410512950, http://dx.doi.org/10.1108/14691930410512950

Chen, M.C., Cheng, S. J., \& Wang, Y. C. (2005). An Empirical Investigation of the Relationship between Intellectual Capital and Firms' Market Value and Financial Performance. Journal of Intellectual Capital, Vol. 6, No. 2 ABI/INFORM Global, pp.156-176. doi:10.1108/14691930510592771, http://dx.doi.org/10.1108/14691930510592771

Donaldson, T., Preston, L.E. (1995). The Stakeholder theory of the corporation: concepts, evidence and implication. Academy of Management Review, Vol. 20 No. 1, pp. 65-91. doi:10.2307\%2F258887, http://dx.doi.org/10.2307\%2F258887

Edvinsson, L. (1997). Developing Intellectual Capital at Skandia. Long Range Planning, Vol. 30, No. 3, pp. 266-373. doi:10.1016\%2FS0024-6301\%2897\%2900016-2, http://dx.doi.org/10.1016\%2FS0024-6301\%2897\%2900016-2

Firer, S., \& Williams, S. M. (2003). Intellectual Capital and Traditional Measures of Corporate Performance. Journal of Intellectual Capital, Vol. 4 No. 3, pp.348- 360. doi:10.1108/14691930310487806, http://dx.doi.org/10.1108/14691930310487806

Galunic C., Anderson E. (2000). From security to mobility: Generalized investments in Human Capital.

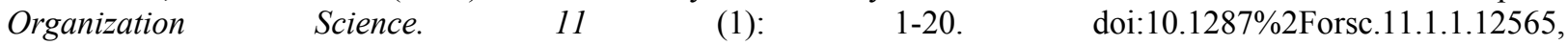
http://dx.doi.org/10.1287\%2Forsc.11.1.1.12565

García-Meca, E., Martínez, I. (2005). Assessing the quality of disclosure on intangibles in the Spanish capital market. European Business Review, Vol. 17 No.4, pp.305. doi:10.1108/09555340510607352, http://dx.doi.org/10.1108/09555340510607352

Gigante G., Previati D. (2010). The Performance of Intellectual Capital and Banking: Some Empirical Evidence from the European Banking System, in F. Fiordelisi, P. Molineux, D. Previati (editors), New Issues in Financial Institutions Management, Palgrave Macmillan Studies in Banking and Financial Institutions, Palgrave Macmillan.

Guthrie, J., Petty, R. (2000). Intellectual Capital: Australian Annual Reporting Practices. Journal of Intellectual Capital, Vol. 1 No.3, pp.241. doi:10.1108/14691930010350800, http://dx.doi.org/10.1108/14691930010350800

Hall, N.G., Stivers, B., Covin, T. and Smalt, S. (1996). Fuzzy logic tools needed for Intellectual Capital management systems, Proceedings of the Conference of the North American Fuzzy Information Processing Society. NAFIPS, p327-330. doi:10.1109/NAFIPS.1996.534753, http://dx.doi.org/10.1109/NAFIPS.1996.534753

Kaplan, R.S. and Norton, D.P. (1992). The Balanced Scorecard - measures that drives performance. Harvard Business Review, Vol. 70, No. 1, pp. 71-79.

Lev, B. (2001). Intangibles: Management and Reporting. Brookings Institution Press, Washington, DC. doi:10.1108/13683040410524694, http://dx.doi.org/10.1108/13683040410524694

Lev, B., and Radhakrishnan, S. (2003). The Measurement of Firm- Specific Organizational Capital. NBER Working Paper, No. 9581, available at: www.nber.org/papers/w9581

Lev, B., and Zarowing, P. (1999). The Boundaries of Finance Reporting and How to Extend Them. Journal of Accounting Research, Vol. 37, Autumn, pp.353-385. doi:10.2307\%2F2491413, http://dx.doi.org/10.2307\%2F2491413

Mavridis, D.G (2005). Intellectual Capital Performance Drivers in the Greek Banking Sector. Management Research News, 28, 5, 43-62. doi:10.1108\%2F01409170510629032, http://dx.doi.org/10.1108\%2F01409170510629032

Miller, M. (1999). Leveraging your Hardwired Intellectual Capital. Strategy and Leadership Journal, March-April, 1999, p28-39. doi:10.1108\%2Feb054633, http://dx.doi.org/10.1108\%2Feb054633

Mouritsen, J., Bukh, P.N., Marr, B. (2004). Reporting on Intellectual Capital: why, what and how. Measuring Business Excellence, Vol. 8 No.1, pp.46-54. doi:10.1108\%2F13683040410524739, http://dx.doi.org/10.1108\%2F13683040410524739 
Ortiz, Miguel Angel Axtle (2009). Analysis and Valuation of Intellectual Capital According to its Context. Journal of Intellectual Capital, Vol. 10, No. 3, pp.451 - 482. doi:10.1108/14691930910977833, http://dx.doi.org/10.1108/14691930910977833

Previati D., Vezzani P. (2010). Managerial Research Framework in Banking: Intellectual Capital and Stakeholder Management.The case of Human Resource Management and Voluntary Disclosure, in "Economia Aziendale \& Management: scritti in onore di Vittorio Coda" (a cura di G. Airoldi, G. Brunetti, G. Corbetta e G. Invernizzi), Università Bocconi Editore, ISBN 978-88-8350-162-3.

Pulic, A. (1998). Measuring the performance of intellectual potential in knowledge economy. Available at: http://www.vaic-on.net/start.htm (accessed 19 August 2006).

Pulic, A. (2000a). VAICTM - an Accounting Tool for IC Management. International Journal Technology Management, 20(5/6/7/8), pp.702-714.

Pulic, A. (2000b). MVA and VAIC analysis of randomly selected companies from FTSE 250. Available at: http://www.vaic-on.net/start.htm (accessed 19 August 2006).

Ranjith A. B. (2007). The Impact Of Intellectual Capital On Investors' Capital Gain On Shares: An Empirical Investigation In Thai Banking, Finance \& Insurance Sector. Journal of Internet Banking and Commerce, 12, (1), 111-134. http://www.arraydev.com/commerce/jibc/

Riahi- Belkaoui, A. (2003). Intellectual Capital and Firm Performance of US Multinational Firms: a Study of the Resource- Based and Stakeholder Views. Journal of Intellectual Capital, Vol.4 No. 2, pp.215-226. doi:10.1108\%2F14691930310472839, http://dx.doi.org/10.1108\%2F14691930310472839

Ross, G. \& Ross, J. (1997). Measuring your company's intellectual performance. Long Range Planning, Vol. 30 No.3, pp.413-426. doi:10.1016\%2FS0024-6301\%2897\%2900022-8, http://dx.doi.org/10.1016\%2FS0024-6301\%2897\%2900022-8

Saint-Onge, H. (1996). Tacit Knowledge: The Key to the Strategic Alignment of Intellectual Capital. Strategy \& Leadership (April). doi:10.1108\%2Feb054547, http://dx.doi.org/10.1108\%2Feb054547

Stewart, Thomas A. (1997). Intellectual Capital. The New Wealth of Organizations, Doubleday, New York. doi:10.1002\%2Fpfi.4140370713, http://dx.doi.org/10.1002\%2Fpfi.4140370713

Sullivan, P. (2000). Value-Driven Intellectual Capital - How to Convert Intangible Corporate Assets into Market Value, New York. John Wiley and Sons. ISBN: 0471351040

Sveiby, K.E. (1997). The New Organizational Wealth: Managing and Measuring Knowledge-based Assets. Berrett-Koehler, New York, NY. ISBN: 1-57675-014-0

\section{Notes}

Note 1. Banca Intra was an independent bank operating in Italy since 1873. Notwithstanding good financial performance until 2006, it was submitted in 2007 to the Italian banking crisis procedures and then incorporated in Veneto Banca, ending forever its existence as independent bank. 
Table 1. Review of the Literature on Intellectual Capital Issue

\begin{tabular}{|c|c|c|}
\hline Author/Source & Concept Defined & Definition/Interpretation \\
\hline Bontis(2003) & IC & $\begin{array}{l}\text { Means individual workers' and organizational knowledge that contributed to sustainable } \\
\text { competitive advantage. }\end{array}$ \\
\hline $\begin{array}{l}\text { Bornemann et al. } \\
(1999)\end{array}$ & IC & $\begin{array}{l}\text { Found enterprises, which manage their IC better, owned stronger competitive advantage than } \\
\text { the general enterprises }\end{array}$ \\
\hline Bouty, (2000) & IC & $\begin{array}{l}\text { Find two sets of definitions (individual and collective approach) but also temporal approach to } \\
\text { IC. According to Bouty, IC can create value in the future, or has the potential to create value. }\end{array}$ \\
\hline Bradley (1997) & IC & $\begin{array}{l}\text { Bradley notes that last } 30 \text { years represent } 90 \% \text { of what is known about physics, chemistry, and } \\
\text { biology. In the same article, he also states that "....knowledge is currently doubling every } 18 \\
\text { months and, of course, the pace is increasing." }\end{array}$ \\
\hline $\begin{array}{l}\text { Brennan }(2001, \mathrm{p} . \\
423)\end{array}$ & IC & $\begin{array}{l}\text { Encompasses intangibles, such as patents, intellectual property rights, Copyrights and } \\
\text { franchises. }\end{array}$ \\
\hline $\begin{array}{l}\text { Chen et al. }(2004, \\
\text { p. 201) }\end{array}$ & $\begin{array}{l}\text { IC: } \\
\text { Human Capital }\end{array}$ & $\begin{array}{l}\text { Is constituted by "such factors as employee knowledge, skill, capability, and attitudes in } \\
\text { relation to fostering performances customers are willing to pay for and which the company's } \\
\text { profit comes from". }\end{array}$ \\
\hline $\begin{array}{l}\text { Galbraith (1969) in } \\
\text { Sullivan (2000) }\end{array}$ & IC & $\begin{array}{l}\text { It is more than purely intellectual, and it includes "intellectual action". It is the difference } \\
\text { between having knowledge and using it that literature has tried to capture. The "use" of the } \\
\text { knowledge implies the relationship (social capital) and processes (structural capital) are } \\
\text { needed to transform knowledge (individual) into a product or service that is of value to the } \\
\text { firm and its stakeholders. }\end{array}$ \\
\hline $\begin{array}{l}\text { Galunic and } \\
\text { Anderson }(2000, p \text {. } \\
\text { 3) }\end{array}$ & IC:Human Capital & $\begin{array}{l}\text { Can be defined as "the know-how, information, relationships, and general capabilities that } \\
\text { individuals bring to bear on behalf of the firm through the employment relation". }\end{array}$ \\
\hline Hall et al., (1996) & IC & $\begin{array}{l}\text { IC is defined as "the sum and synergy of a company's knowledge, experience, relationships, } \\
\text { processes, discoveries, innovations, market presence and community influence". A distinction } \\
\text { is often made between human capital—an organization's people and knowledge assets, and } \\
\text { structural capital - the knowledge assets contained within processes, documents, courses, } \\
\text { databases, etc. }\end{array}$ \\
\hline Lev (2001) & $\begin{array}{l}\text { Intangibles: Knowledge } \\
\text { Assets and IC }\end{array}$ & $\begin{array}{l}\text { A claim to future benefits that does not have a physical or financial (a stock or a bond) } \\
\text { embodiment. }\end{array}$ \\
\hline $\begin{array}{l}\text { Martinez and } \\
\text { Garcia-Meca } \\
(2005)\end{array}$ & IC & $\begin{array}{l}\text { The knowledge, information, intellectual property and experience that can be put to use to } \\
\text { create wealth. }\end{array}$ \\
\hline $\begin{array}{l}\text { Miguel Angel } \\
\text { Axtle } \\
\text { Ortiz (2009) } \\
\end{array}$ & Intangible Assets & $\begin{array}{l}\text { An intangible is defined as something not tangible; something that has no physical existence } \\
\text { and incapable of being perceived by the sense of touch, as an incorporeal, immaterial and } \\
\text { impalpable thing. }\end{array}$ \\
\hline $\begin{array}{l}\text { Mouritsen et al. } \\
(2004)\end{array}$ & IC & $\begin{array}{l}\text { Broad organizational knowledge unique to a firm, which allows it constantly to adapt to } \\
\text { changing conditions. }\end{array}$ \\
\hline $\begin{array}{l}\text { Petty and Guthrie, } \\
(2000)\end{array}$ & Knowledge management & $\begin{array}{l}\text { Is about the management of the IC controlled by a company.Knowledge management, as a } \\
\text { function, describes the act of managing the object, IC. }\end{array}$ \\
\hline \begin{tabular}{|l|} 
Riahi-Belkaoui \\
$(2003$, p. 217)
\end{tabular} & IC & $\begin{array}{l}\text { Generates innovation - whether of new products and services or improving business } \\
\text { processes. }\end{array}$ \\
\hline Roos/Roos (1997) & IC & $\begin{array}{l}\text { The sum of the hidden assets of a company not fully captured on its balance sheet, which } \\
\text { includes both what is in the heads of organizational members, and what is left in the company } \\
\text { when these members leave }\end{array}$ \\
\hline Saint-Onge (1996) & $\begin{array}{l}\text { IC : } \\
\text { Customer Capital }\end{array}$ & $\begin{array}{l}\text { It is a form of relational capital, which in effect encompasses the knowledge embedded in all } \\
\text { the relationships an organization develops, whether from customers, from the competition, } \\
\text { from suppliers, from associations or from the government (Bontis, 1999). One manifestation of } \\
\text { relational capital that can be leveraged from customers is often referred to as "market } \\
\text { orientation". }\end{array}$ \\
\hline Stewart (1997) & $\begin{array}{l}\text { IC: } \\
\text { Structural Capital, Human } \\
\text { Capital and Customers' } \\
\text { Capital }\end{array}$ & $\begin{array}{l}\text { Human capital has as main purpose thinking and innovating processes, it doesn't belong to the } \\
\text { organization and it is lost when employees leave. Structural capital belongs to the } \\
\text { organization. It can be reproduced and shared as technology, inventions, data, publications, } \\
\text { strategy, organizational culture, procedures and systems. Clients capital is composed by } \\
\text { relations between the clients and the organization, customer retention, profit and lose per } \\
\text { client. }\end{array}$ \\
\hline Wiig (1997) & Knowledge Management & $\begin{array}{l}\text { Knowledge management is defined as "the systematic, explicit and deliberate building, } \\
\text { renewal and application of knowledge to maximize an organization's knowledge-related } \\
\text { effectiveness and returns from its knowledge assets." Knowledge management is about getting } \\
\text { the right knowledge to the right people, in the right form and in a timely fashion, so they can } \\
\text { do their best work }\end{array}$ \\
\hline
\end{tabular}


Table 2. List of Italian Banks Analyzed

\begin{tabular}{|c|c|c|c|c|c|}
\hline Ranking & $\begin{array}{l}\text { Bank } \\
\end{array}$ & Vaic & Ranking & Bank & Vaic \\
\hline 1 & CREDEM & 629 & 12 & UBI & 2,34 \\
\hline 2 & MEDIOBANCA & 5,14 & 13 & $\begin{array}{l}\text { CREDITO } \\
\text { VALTELLINESE }\end{array}$ & 2,22 \\
\hline & BANCA & & & BANCA & \\
\hline 3 & $\begin{array}{l}\text { FINNAT } \\
\text { CREDITO }\end{array}$ & 3,13 & 14 & CARIGE & 2,09 \\
\hline 4 & BERGAMASCO & 3,08 & 15 & POP SPOLETO & 2,04 \\
\hline 5 & UNICREDITO & 2,97 & 16 & $\begin{array}{l}\text { POP MILANO } \\
\text { CREDITO }\end{array}$ & 1,96 \\
\hline 6 & $\begin{array}{l}\text { IW BANK } \\
\text { POP VERONA }\end{array}$ & 2,72 & 17 & $\begin{array}{l}\text { ARTIGIANO } \\
\text { BANCA POP }\end{array}$ & 1,96 \\
\hline 7 & $\begin{array}{l}\text { NOVARA } \\
\text { BANCA }\end{array}$ & 2.69 & 18 & ETRURIA & 1.93 \\
\hline 8 & INTESA & 2,67 & 19 & $\begin{array}{l}\text { MPS } \\
\text { BANCO }\end{array}$ & 1,93 \\
\hline 9 & $\begin{array}{l}\text { POP SONDRIO } \\
\text { EMILIA }\end{array}$ & 2,66 & 20 & SARDEGNA & 1,64 \\
\hline 10 & $\begin{array}{l}\text { ROMAGNA } \\
\text { BANCO DESIO }\end{array}$ & 2,64 & 21 & MELIORBANCA & 0,18 \\
\hline 11 & BRIANZA & 2.62 & 22 & POP INTRA & $(0.27)$ \\
\hline
\end{tabular}

Vaic Mean for Italian banks on four years evaluation (2003-2007)

Table 3. Descriptive Statistics: VAIC, CEE, HCE, SCE, MRi

\begin{tabular}{lrrrrrrrrr}
\hline Variable & N & $N^{\prime}$ & Mean & \multicolumn{1}{c}{ SEMean } & StDev & Minimum & Q1 & Median & Q3 \\
\hline vaic & 44 & 0 & 2.403 & 0.218 & 1.448 & -1.039 & 1.776 & 2.416 & 2.847 \\
cee & 44 & 0 & 0.2792 & 0.0311 & 0.2061 & -0.5097 & 0.2193 & 0.3339 & 0.394 \\
hce & 44 & 0 & 1.773 & 0.204 & 1.356 & -2.023 & 1.433 & 1.673 & 1.983 \\
sce & 44 & 0 & 0.5089 & 0.0574 & 0.3805 & -0.0619 & 0.3315 & 0.4248 & 0.5359 \\
mri & 44 & 0 & 11.72 & 2.54 & 16.82 & -17.45 & 1.55 & 9.64 & 23.25 \\
Variable & Maximum & & & & & & & \\
vaic & 7.2 & & & & & & & \\
cee & 0.6 & & & & & & & \\
hce & 6.2 & & & & & & & \\
sce & 2 & & & & & & & \\
mi & 56 & & & & & & & \\
\hline
\end{tabular}

Source: Minitab Elaborations

Table 4. Regression Analysis on (Mri)

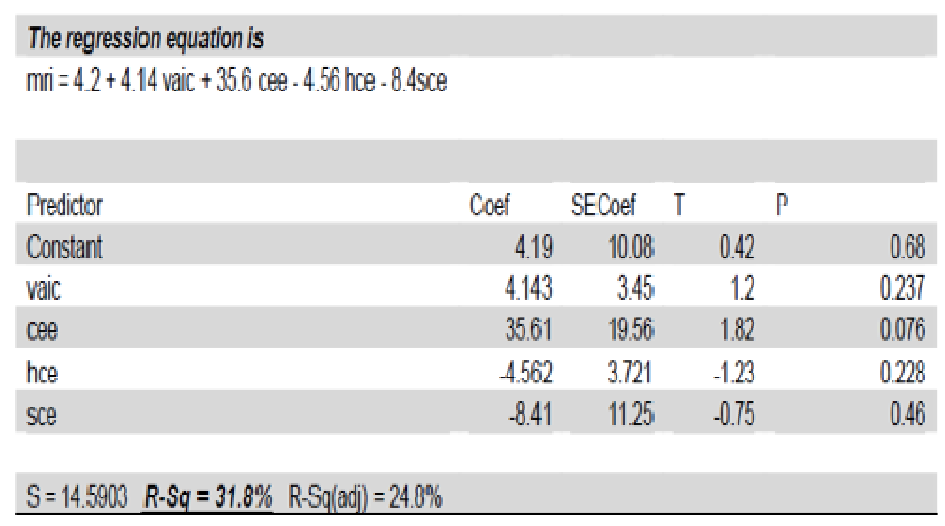

Source: Minitab Elaborations 


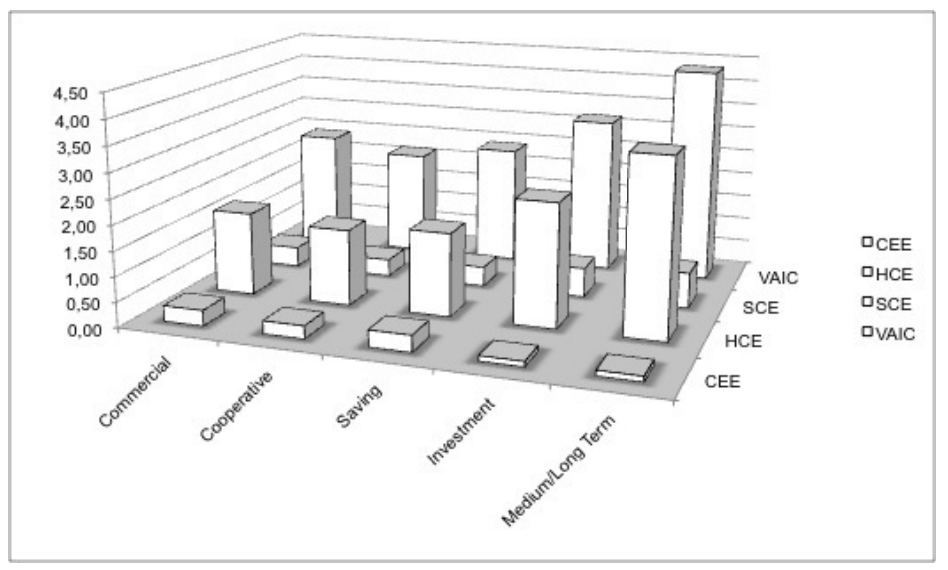

Figure 1. VAIC's values for Italian Banking Sectors

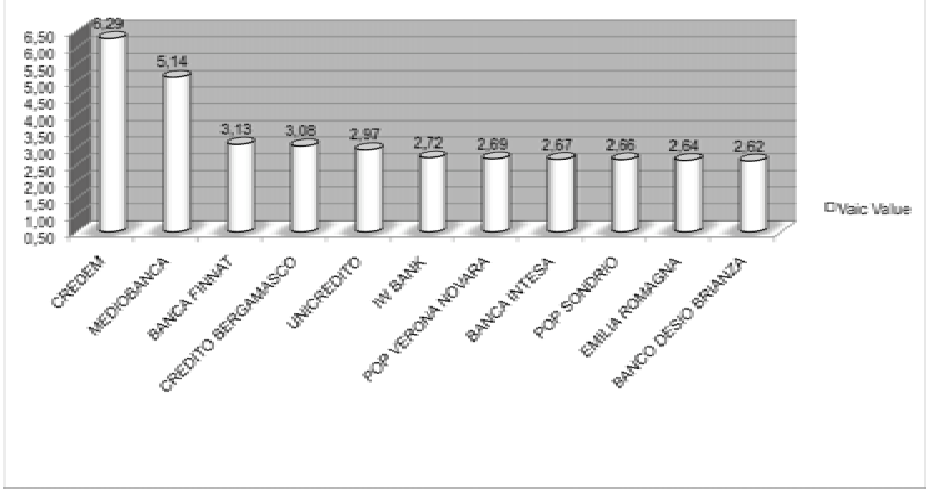

Figure 2. Best Italian banks in terms of VAIC performances in the period 2003-2007

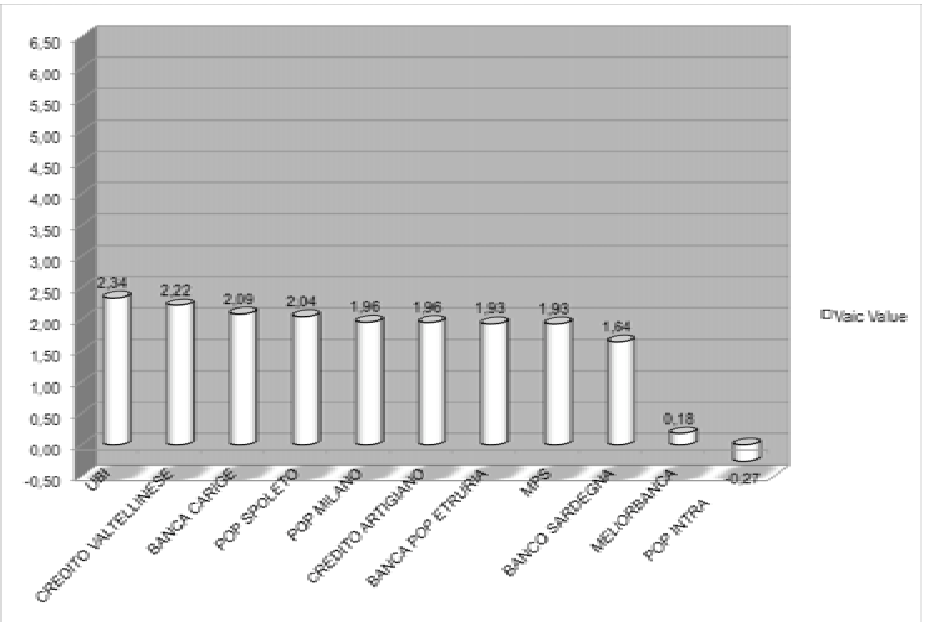

Figure 3. Worst Italian banks in terms of VAIC performances in the period 2003-2007 


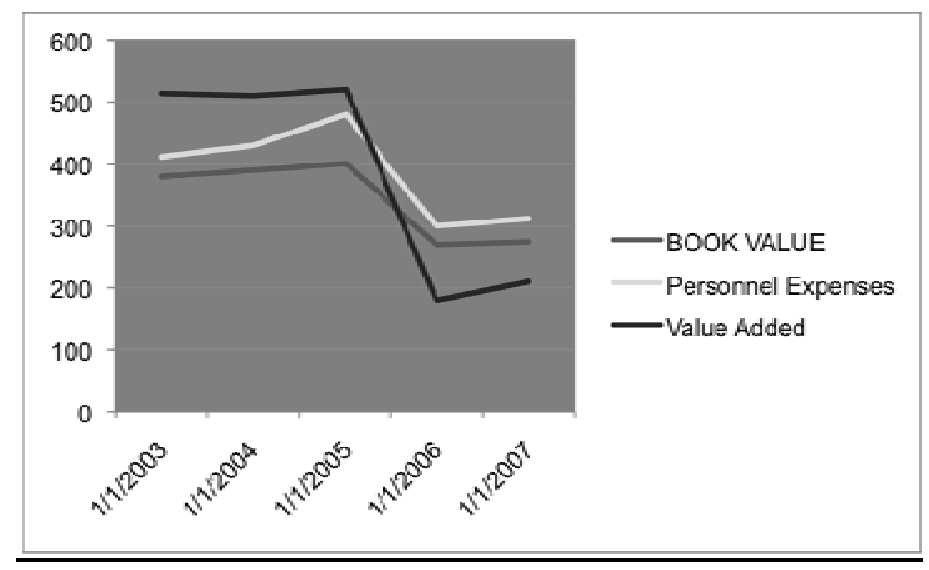

Figure 4. Banca Intra's Performances, measured in Milion Euros 2003-2007

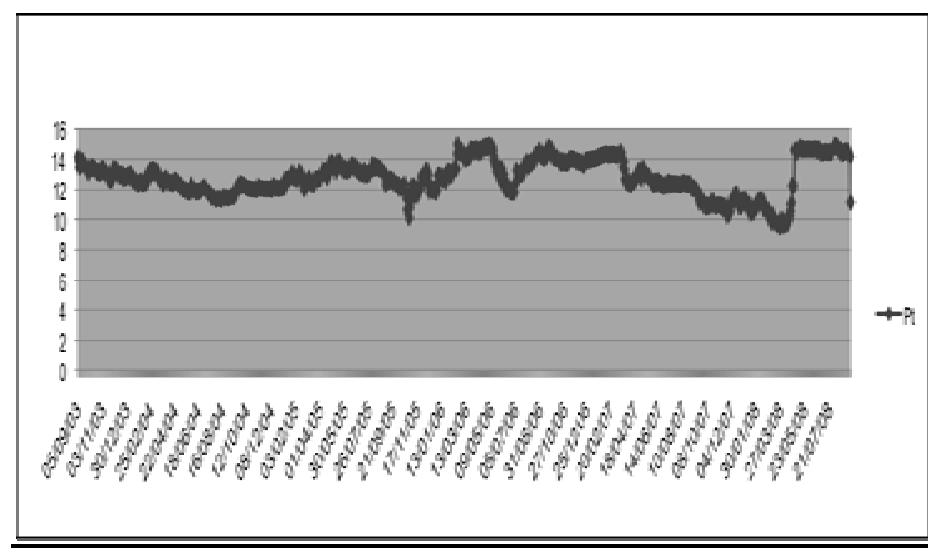

Figure 5. Stock Price (Pt Price at closing date t) Banca Intra 2003-2007

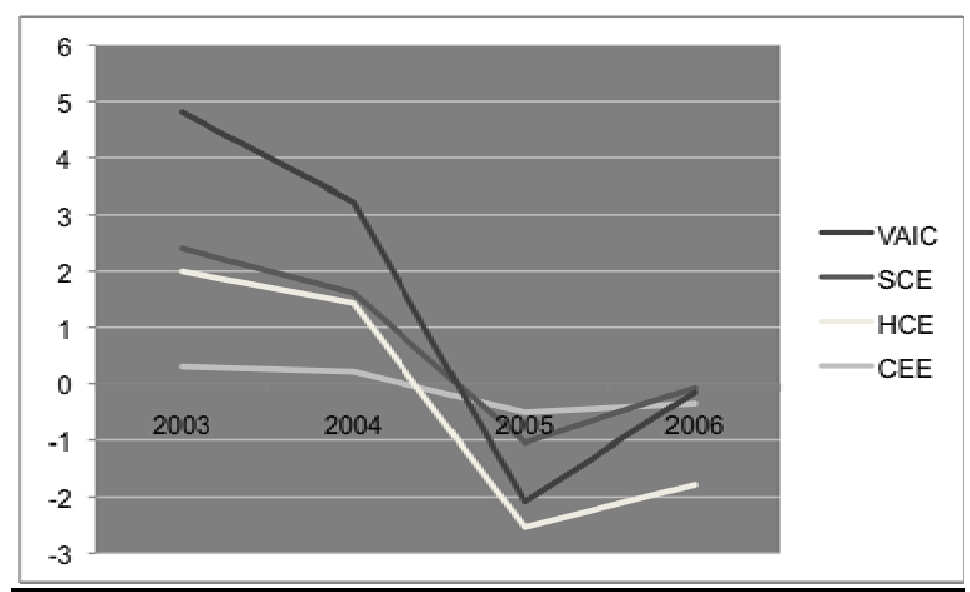

Figure 6. Deflation of VAIC components for Banca Intra 